\title{
TRH: Pathophysiologic and Clinical Implications
}

\author{
C. R. Pickardt ${ }^{1}$ and P. C. Scriba ${ }^{2}$ \\ 1 Medizinische Klinik Innenstadt der Universität München, Federal Republic of Germany \\ ${ }^{2}$ Klinik für Innere Medizin der Medizinischen Hochschule Lübeck, Federal Republic of Germany
}

\section{Summary}

Thyrotropin releasing hormone is thought to be a tonic stimulator of the pituitary TSH secretion regulating the setpoint of the thyrotrophs to the suppressive effect of thyroid hormones. The peptide stimulates the release of normal and elevated prolactin. ACTH and GH may increase in response to exogenous TRH in pituitary ACTH and GH hypersecretion syndromes and in some extrapituitary diseases.

The pathophysiological implications of extrahypothalamic TRH in humans are essentially unknown.

The TSH response to TRH is nowadays widely used as a diganostic amplifier in thyroid diseases being suppressed in borderline and overt hyperthyroid states and increased in primary thyroid failure. In hypothyroid states of hypothalamic origin, TSH increases in response to exogenous TRH often with a delayed and/or exaggerated time course.

But in patients with pituitary tumors and suprasellar extension TSH may also respond to TRH despite secondary hypothyroidism. This TSH increase may indicate a suprasellar cause for the secondary hypothyroidism, probably due to portal vessel occlusion. The TSH released in these cases is shown to be biologically inactive.

Keywords: TRH; diagnostic significance; hypothalamic diseases; pituitary failure.

$\mathrm{TRH}$, initially detected and synthesized as the hypothalamic hormone that controls the thyrotrophic activity was found to stimulate the prolactin release in vivo and in vitro $43,45,63,72,77$. Moreover, TRH has been shown to be widely distributed over the central nervous system $^{36}, 37,44,71$, where it is believed to have neurotransmitter functions besides the hypophysiotropic effects.

TRH has been detected in the upper gastrointestinal tract ${ }^{14}$, where its endogenous functions are unknown. Exogenous TRH inhibits the pentagastrin stimulated gastric secretion ${ }^{12}$ and by some degree the glucagon and pancreatic polypeptide release after insulin induced hypoglycemia ${ }^{13}$.

\section{TRH and Thyrotropic Activity}

Experimental and pathological disruption of the hypothalamic supply of the pituitary with TRH results in decreased thyroid function ${ }^{47}$, called secondary hypothyroidism. TRH antibodies induce impairment of thyroid function with some effects on the prolactin secretion as well $28,32,39,76$. But until now, there are no consistent data on the physiological hypothalamopituitary relationship in humans. This is due to the fact that serum and urinary TRH is mainly derived from extrahypothalamic sources ${ }^{46}$. In experimental hypoand hyperthyroidism the hypothalamic content of TRH does not change ${ }^{52}$ arguing against a feedback inhibition between TRH and TSH. There are few studies reporting a decrease of TRH in hyper- and an increase in hypothyroidism with marked differences in the reported normal levels ${ }^{29,50}$. Most authors postulate today that TRH is a tonic stimulator of the TSH secretion, modulating the set point of the thyrotrophs to the suppressive effect of thyroid hormones ${ }^{47}$.

TSH responses to TRH are modulated by estrogens in females and in males ${ }^{20}$. This modulation is due to increasing binding sites of pituitary cells under estrogen influence which can be partly antagonized by thyroid hormones ${ }^{42}$.

Repetitive intravenous and chronical oral TRH administration in euthyroid and hypothyroid individuals results in a decrease of serum TSH $1,4,34,38,62,75$ and in euthyroids in an increase of thyroid hormones within the upper normal range 3, 34,62. The TSH decrease following TRH administration was also observed in athyroid patients ${ }^{75}$. The latter finding may be suggestive for down regulation of the TRH receptor of the thyrotrophs which is transient ${ }^{62}$, or for a predominant stimulation of TSH release and a slower de novo synthesis of pituitary $\mathrm{TSH}^{38}$. The simultaneous de- 
crease of PRL under these conditions was more pronounced ${ }^{51}$.

The thyrotropic activity is under an inhibitory control of somatostatin ${ }^{78}$ and dopamine $5,11,27,48,63,66$, which is more evident in euthyroids, mild and treated hypothyroidism than in severe hypothyroidism ${ }^{8}, 25$. Dopamine modulates the diurnal variations of $\mathrm{TSH}^{67},{ }^{74}$. In states with increased hypothalamic dopamine turnover the tonic inhibition of TSH is thought to be enhanced ${ }^{68}$. This seems to have no clinical implications since oral treatment with dopamine agonists ${ }^{40}$ and antagonists ${ }^{81}$ does not influence TSH levels and TSH response to TRH.

\section{TRH and Other Pituitary Hormones}

In normal adults TRH does not influence the release of $\mathrm{GH}$ and $\mathrm{ACTH}{ }^{53}$. In states with borderline or overt functional disturbances of the GH producing cells, such as active acromegaly ${ }^{82,83}$, children with constitutional tall stature and elevated somatomedin levels ${ }^{17}$ and in type I diabetes, predominantly in females ${ }^{7}$ and in newborns, when TRH was administered to the mother shortly before delivery ${ }^{64}$, TRH may stimulate $\mathrm{GH}$ release. In addition, TRH reduces the somatostatin induced inhibition of $\mathrm{GH}$ release in vitro ${ }^{16}$.

TRH stimulates prolactin release in normal, hyperand hypothyroid individuals ${ }^{43,45,63}$. Elevated prolactin levels have been observed in patients with primary hypothyroidism and can be lowered by thyroid hormones. In hyperthyroidism mean prolactin levels are lower as compared to normals and increase during antithyroid treatment ${ }^{72}$. Recently, specific inhibition of prolactin synthesis (decrease of PRL $\mathrm{m}$ RNA) by T 3 in vitro was shown ${ }^{49}$.

In normals prolactin is mainly under the inhibitory hypothalamic control and the observed modulation of prolactin secretion by TRH gain clinical significance only in severe hypothyroidism.

In prolactinomas the TRH induced prolactin increase is low with high basal levels of prolactin and vice versa ${ }^{26}$.

In patients with Cushing's disease ${ }^{61}$ TRH may induce a paradoxical rise of ACTH.

Thus, TRH like GnRH may be recognized as a stimulator by non thyrotropic pituitary cells under pathological conditions.

\section{Modulation of the TSH Response to TRH by Non- thyroidal Endocrine and Non-Endocrine Diseases}

The TSH response to TRH is nowadays widely used as a diagnostic tool in thyroidology. Therefore, it was necessary to evaluate factors and hormones which modulate the TSH response in non-thyroidal endocrine and non-endocrine diseases.

In Cushing's syndrome irrespective of the pathogenesis and during glucocorticosteroid pharmacotherapy basal TSH and TSH response may be blunted or suppressed $21,41,54,73,84$, and return to normal after successful treatment of hypercortisolism. In Addison's disease moderately elevated basal TSH levels have been observed ${ }^{3}$.

In patients with active acromegaly blunted TSH response to TRH has been reported ${ }^{10,82}$ and TSH response may be elevated in GH deficiency ${ }^{10}$.

Recently, diminished TSH stimulation has been reported in chronic hypercalcemia and a pronounced increase in hypoparathyroid individuals ${ }^{33}$, variations which return to normal after correction of serum calcium levels.

There is an increasing number of data on decreased TSH response to TRH in patients with severe nonthyroidal illness and during total fasting ${ }^{35,} 70$. The pathogenesis of these disturbances in the TSH responsiveness of the pituitary is not yet well understood. Patients do not exhibit clinical signs of hypothyroidism despite the concomittant development of considerable alterations in the peripheral thyroid hormone metabolism. These phenomena were recently reviewed ${ }^{80}$.

These modulations of the TSH response to TRH in endocrine and non-endocrine diseases have to be kept in mind when using the TRH-test for clinical purposes.

\section{TRH Test in Diagnosis of Hypothalamic and Pituitary Diseases}

When TRH became available for clinical investigations, the TRH-test was expected to differentiate between hypothalamic and pituitary origin of central hypothyroidism. Patients with hypothyroidism of obvious hypothalamic origin were shown to have the expected response of TSH to $\mathrm{TRH}^{31,56,58,69}$, which is often delayed and or exaggerated 19, 22, 23.

But patients with pituitary tumors, suprasellar extension and visual field impairment exhibited an unexpected TSH response to TRH ${ }^{19}, 56$ which is often delayed and exaggerated as well. The net increment of TSH may not differ from normals or from euthyroid patients with pituitary tumors (Fig. 1).

In none of our patients the TSH-response to TRH was completely absent before pituitary surgery and only in some of them postoperatively ${ }^{56,57}$.

Similar data were reported from other groups 19,31 , 55. Thus, the failure of TRH test to differentiate 
between hypothalamic and pituitary insufficiency was documented.

These findings allow at least two hypothetical explanations. From our data in patients with large pituitary tumors we suggested, that the increase of TSH levels after TRH indicates a suprasellar cause of

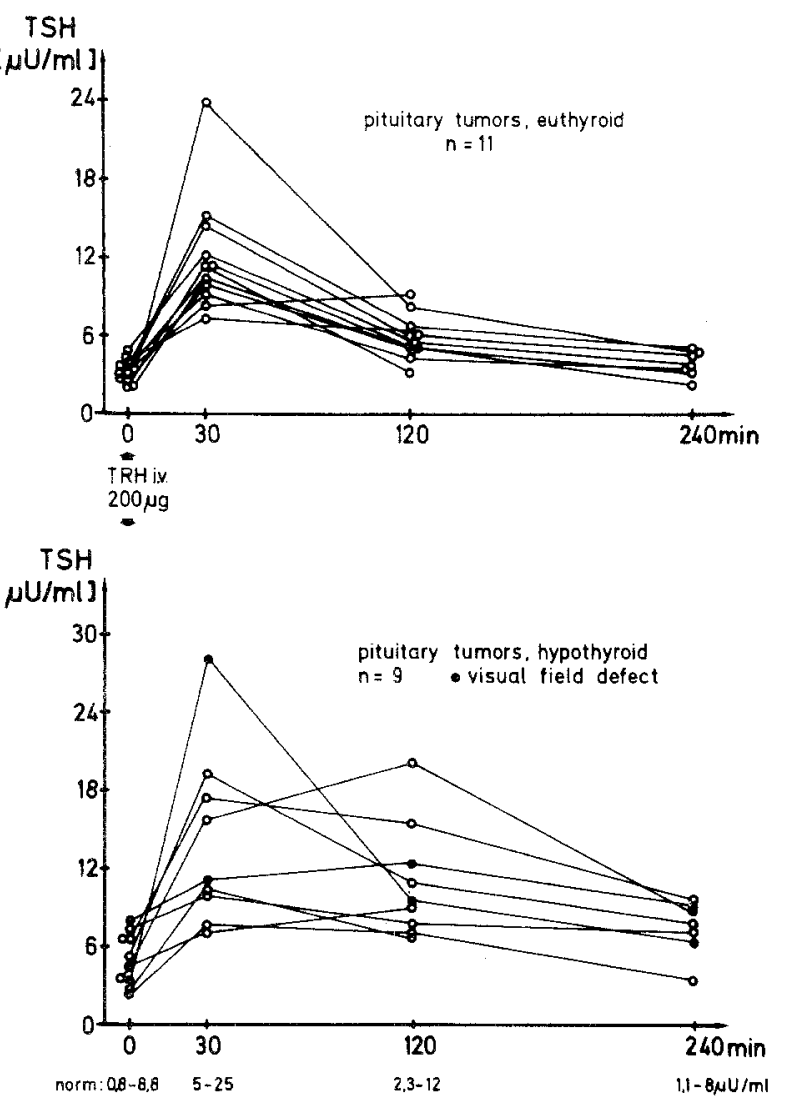

Fig. 1. TSH-response to TRH in patients with pituitary tumors. The upper panel depicts the TSH-response to TRH in 11 euthyroid patients, in the lower panel the TSH-response in 9 hypothyroid patients is demonstrated

secondary hypothyroidism, probably due to a partial occlusion of the portal vessel system, thus preventing the endogenous TRH from reaching the remaining pituitary thyrotrophs $56,57,58,69$. This explanation was picked up very recently for the recovery of partial pituitary insufficiency after treatment of large inactive pituitary tumors ${ }^{2}$ and for a moderate increase in PRL levels after irradiation of the pituitary in acromegaly ${ }^{9}$.

Faglia and coworkers initially postulated the secretion of a biologically inactive $\mathrm{TSH}^{19}$. In further investigations they documented an impaired $\mathrm{T} 3$ increase after TRH induced elevation of the TSH levels ${ }^{22}$ and diminished biological activity of the TSH in a cytochemical bioassay despite immunoidentity to standard $\mathrm{TSH}^{23}$. More recently, the group published the observation of an elevated ratio of $\beta$ TSH to $\alpha$ TSH subunit in idiopathic central hypothyroidism ${ }^{24}$. Oral treatment with TRH in one patient resulted in a decrease of the $\beta / \alpha$ ratio and his thyroid became responsive to the endogenous TRH-stimulated TSH. The authors conclude that TRH may be imperative in the secretion of TSH with full biological potency.

\section{TRH Test as a Thyroid Function Test}

In euthyroid men basal TSH levels as measured by radioimmunoassay are undetectable in about $30 \%$. Thus, by means of basal TSH one can not distinguish suppressed TSH secretion from normal. Therefore, TRH-unresponsiveness of TSH offers more information. The test is nowadays used as an amplifyer in cases of borderline hyperthyroidism in "euthyroid" Graves' disease before and after treatment, in cases with autonomous functioning solitary and multiple adenomas and in nodular goiters ${ }^{30}$. Using the TRH test for routine purposes it became obvious that in our hospital population in 446 patients observed over a period of 12 months TSH suppression was due to preclinical hyperthyroidism in $88(20) \%$. Out of these about $44 \%$ were iodine contaminated. In our area with nutritional iodine deficiency, endemic goiter and an increased prevalence of autonomous adenomas, patients at risk for hyperthyroidism are more easily detected by TRHtest as compared to investigations of the peripheral thyroid hormone levels alone. In this context it may be of interest that in the course of longterm treatment with the antiarhythmic drug Amiodarone about $30 \%$ of bavarian patients developed preclinical hyperthyroidism $^{60}$.

By the combination of TRH stimulation test and the scinti-scans autonomous adenoma ${ }^{59}$ can be classified into different groups depending on the extent of TSH suppression. For economical reasons some European investigators use the test as a first step diagnostic tool.

In primary thyroid failure exaggerated TSHresponse may indicate earlier thyroid insufficiency, undetectable by clinical signs, lowered thyroid hormones or elevated basal TSH, a situation found in about $20 \%$ of patients with endemic goiter in this area.

\section{Therapeutical Aspects}

Experimental investigations of cardiovascular function and survival rates in endotoxic shock gave rise to the conclusion that TRH administered intravenously in high dosages improves the outcome in experimental animal models. In addition, Faden and coworkers observed a significantly better neurological recovery after spine injury in cats ${ }^{18}$. They explain these effects by 
a partial opiate antagonism of TRH because similar effects occur during treatment with naloxone.

In humans, TRH was found to improve ataxia in patients with spinocerebellar degeneration. Recently, Engel and coworkers ${ }^{15}$ reported marked improvement of weakness and spasticity in amyotrophic lateral sclerosis after TRH i.v. The justification for treatment was derived from the observation in animals, where TRH has been detected in nerve endings in the ventral horn of lower motor neurons and in nerve endings in motor nuclear V, VII, XII. In a preliminary study the authors found reduced TRH levels in CSF of patients with amyotrophic lateral sclerosis and other spastic diseases.

Because amyotrophic lateral sclerosis is a progressive disease, these observations prompted us to initiate a pilot study with oral TRH in one patient who is presently under investigation.

\section{References}

1. Ahuja, S., Baumgarten, S., Oeff, K., Repetitive intravenous TRH-stimulations at short intervals in euthyroid and hypothyroid subjects. Acta Endocrinol. (Kbh) 93 (1980), 20-24.

2. Arafah, B. M., Brodkey, J. S., Manni, A., Velasco, M. E., Kaufmann, B., Pearson, O. H., Recovery of pituitary function following surgical removal of large nonfunctioning pituitary adenomas. Clinical Endocrinol. 17 (1982), 213-222.

3. Barnett, A. H., Donald, R. A., Espiner, E. A., High concentrations of thyroid stimulating hormone in untreated glucocorticoid deficiency: Indication of primary hypothyroidism? Brit. med. J. 285 (1982), 172-173.

4. Benkert, O., Horn, K., Pickardt, C. R., Schmid, D., Sexual impotence: Studies on the hypothalamic pituitary thyroid axis and the effect of oral thyrotropin releasing factor. Arch. Sex. Behav, 5 (1976), 275-281.

5. Burrow, G. N., May, P. B., Spaulding, S. W., Donabedian, R. K., TRH and dopamine interactions affecting pituitary hormone secretion. J. Clin. Endocrinol. Metab. 45 (1977), 65-72.

6. Carr, C., Gomez-Pan, A., Weightman, D. R., Roy, V. C. M., Hall, R., Besser, G. M., Thorner, M. O., McNeilly, A. S., Schally, A. V., Kastin, A. J., Coy, D. H., Growth hormone release inhibiting hormone: Action on thyrotropin and prolactin secretion after thyrotrophin releasing hormons. Brit. med. J. 3 (1975), 67-69.

7. Ceda, G. P., Speroni, G., Dall'Aglio, E., Valenti, G., Butturini, U., Nonspecific growth hormone responses to thyrotrophin releasing hormone in insulin-dependent diabetes: Sex- and agerelated pituitary responsiveness. J. Clin. Endocrinol. Metab. 55 (1982), 170-- 174

8. Chen, H. J., Meites, J., Effects of biogenic amines and TRH on release of prolactin and TSH in the rat. Endocrinology 96 (1975), $10-22$.

9. Clark, A. J. L., Mashiter, K., Goolden, A. W., Joplin, G. F., Hyperprolactinemia after external irradiation for acromegaly. Clin. Endocrinol. 17 (1982), 291-295.

10. Cobb, W. E., Reichlin, S., Jackson, I. M. D., Growth hormone secretory status is a determinant of the thyrotropin response to thyrotropin releasing hormone in euthyroid patients with hypo- thalamic pituitary diseases. J. Clin. Endocrinol. Metab. 52 (1981), 324-329.

11. Cooper, D. S., Klibanski, A., Ridgway, E. C., Dopaminergic modulation of TSH and its subunits: In vivo and in vitro studies. Clinical Endocrinology 18 (1983), 265-275.

12. Dolva, L. Ø., Hanssen, K. F., Berstad, A., Frey, H. M. M., Thyrotrophin releasing hormone inhibits the pentagastrin stimulated gastric secretion in man, a dose response study. Clinical Endocrinology 10 (1979), 281-286.

13. Dolva, L. Ø., Hanssen, K. F., Flaten, O., Hanssen, L. E., von Schenck, H., The effect of thyrotrophin-releasing hormone (TRH) on pancreatic hormone secretion in normal subjects. Acta Endocrinol. (Kbh) 102 (1983), 224-230.

14. Dolva, L. Ø., Hanssen, K. F., Aadland, E., Sand, T., Thyrotropin-releasing hormone immunoreactivity in the gastrointestinal tract of man. J. Clin. Endocrinol. Metab. 56 (1983), 524-529.

15. Engel, W. K., Siddique, T., Nicoloff, J. T., Effect on weakness and spasticity in amyotrophic lateral sclerosis of thyrotropinreleasing hormone. Lancet $I$ (1983), 73-75.

16. Enjalbert, A., Epelbaum, J., Arancibia, S., Tapia-Arancibia, L., Bluet-Pajot, M. Th., Kordon, C., Reciprocal interactions of somatostatin with thyrotropin-releasing hormone and vasoactive intestinal peptide on prolactin and growth hormone secretion in vitro. Endocrinology 111 (1982), 42-47.

17. Evain-Brion, D., Garnier, P., Schimpff, R. M., Chaussain, J. L., Job, J. C., Growth hormone response to thyrotropin-releasing hormone and oral glucose-loading test in tall children and adolescents. J. Clin. Endocrinol. Metab. 56 (1983), 429-432.

18. Faden, A. I., Jacobs, T. P., Holaday, J. W., Thyrotropinreleasing hormone improves neurologic recovery after spinal trauma in cats. N. Engl. J. Med. 305 (1981), 1063-1067.

19. Faglia, G., Beck-Peccoz, P., Ambrosi, B., Ferrari, C., Neri, V., Prolonged and exaggerated elevations in plasma thyrotropin (HTSH) after thyrotropin releasing factor (TRF) in patients with pituitary tumors. J. Clin. Endocrinol. Metab. 33 (1971), 999 1002.

20. Faglia, G., Beck-Peccoz, P., Ferrari, C., Ambrosi, B., Spada, A., Travaglini, P., Enhanced plasma thyrotrophin response to thyrotrophin releasing hormone following oestradiol administration in man. Clinical Endocrinology 2 (1973), 207-210.

21. Faglia, G., Ferrari, C., Beck-Peccoz, P., Spada, A., Travaglini, P., Ambrosi, B., Reduced plasma thyrotropin response to thyrotropin releasing hormone after dexamethasone administration in normal subjects. Horm. Metab. Res. 5 (1973), 289292.

22. Faglia, G., Ferrari, C., Paracchi, A., Spada, A., Beck-Peccoz, P., Triiodothyronine response to thyrotrophin releasing hormone in patients with hypothalamic-pituitary disorders. Clinical Endocrinology 4 (1975), 585-590.

23. Faglia, C., Bitensky, L., Pinchera, A., Ferrari, C., Paracchi, A., Beck-Peccoz, P., Ambrosi, B., Spada, A., Thyrotropin secretion in patients with central hypothyroidism: Evidence for reduced biological activity of immunoreactive thyrotropin. J. Clin. Endocrinol. Metab. 48 (1979), 989-998.

24. Faglia, G., Beck-Peccoz, P., Ballabio, M., Nava, C., Excess of $\beta$ subunit of thyrotropin (TSH) in patients with idiopathic central hypothyroidism due to the secretion of TSH with reduced biological activity. J. Clin. Endocrinol. Metab. 56 (1983), 908914.

25. Feek, C. M., Sawers, J. S. A., Brown, N. S., Seth, J., Irvine, W. J., 
Toft, A. D., Influence of the thyroid status on dopaminergic inhibition of thyrotropin and prolactin secretion: Evidence of an additional feedback mechanism in the control of thyroid hormone secretion. J. Clin. Endocrinol. Metab. 51 (1980), 585589.

26. Flückiger, E., del Pozo, E., von Werder, K., Prolactin, physiology, pharmacology and clinical findings. Monographs in Endocrinology 23. Berlin-Heidelberg-New York: Springer. 1982

27. Foord, St. M., Peters, J. R., Dieguez, C., Scanlon, M. F., Hall, R., Dopamine receptors on intact anterior pituitary cells in culture: Functional association with the inhibition of prolactin and thyrotropin. Endocrinology 112 (1983), 1567-1577.

28. Fraser, H. M., McNeilly, A. S., Effect of chronic immunoneutralization of thyrotropin releasing hormone on the hypothalamic pituitary thyroid axis, prolactin and reproductive function in the ewe. Endocrinology 111 (1982), 1964-1973.

29. Guignier, F., Pelletier, J. L., Touzery, C., Gailliard, P., Thyrotropin-releasing hormone radioimmunoassay in human serum and its application in thyroidal pathology. Eur. J. Nucl. Med. 6 (1981), 73-78.

30. Habermann, J., Leisner, B., Witte, A., Pickard, C. R., Scriba, P. C., Iodine contamination as a cause of hyperthyroidism or lack of TSH response to TRH stimulation (results based on a screening investigation). J. Endocrinol. Invest. 5 (1982), 153156.

31. Hall, R., Ormston, B. J., Besser, G. M., Cryer, R. J., McKendrick, M., The thyrotrophin-releasing hormone test in diseases of the pituitary and hypothalamus. Lancet $I$ (1972), $754-763$.

32. Hefco, E., Krulich, L., Aschenbrenner, J. E., Effect of hypothalamic deafferentiation on the secretion of thyrotropin during thyroid blockade and exposure to cold in the rat. Endocrinology 97 (1975), 1234-1240.

33. Hiramatsu, K., Hashizume, K., Aizawa, T., Ichikawa, K., Yamada, T., Thyrotropin secretion in patients with hyperparathyroidism or hypoparathyroidism: Effect of serum calcium on thyrotropin release. J. Clin. Endocrinol. Metab. 56 (1983), 623626.

34. Horn, K., Erhardt, F., Fahlbusch, F., Pickardt, C. R., von Werder, K., Scriba, P. C., Recurrent goiter, hyperthyroidism, galactorrhea and amenorrhea due to a thyrotropin and prolactin-producing pituitary tumor. J. Clin. Endocrinol. Metab. 43 (1976), 137-143.

35. Hugues, J.-N., Burger, A. G., Grouselle, D., Voirol, M. J., Chabert, P., Modigliani, E., Sebaoun, J., Evidence of a thyrotropin-releasing hormone dependent increase in plasma thyrotropin during refeeding of starved rats. Endocrinology 112 (1983), $715-719$.

36. Jackson, J. M. D., Thyrotropin releasing hormone (TRH): Distribution in mammalian species and its functional significance. In: Thyrotropin Releasing Hormone (Griffiths, E. C., Benett, G. W., eds.), pp. 3-18. New York: Raven Press.

37. Johannson, O., Hökfelt, T., Jeffcoate, S. L., White, N., Spindel, E., Light and electron microscopic immunohistochemical studies on TRH in the central nervous system of the rat. In: Thyrotropin Releasing Hormone (Griffiths, E. C., Benett, G. W., eds.), pp. 19-32. New York: Raven Press.

38. Klindt, J., Davis, S. L., Ohlson, D. L., Plasma concentration of thyrotropin-releasing hormone, thyrotropin, prolactin and growth hormone during five-day osmotic pump infusion of thyrotropin-releasing hormone. Endocrinology 104 (1979), 4579.
39. Koch, Y., Goldhaber, G., Fireman, I., Zor, U., Shani, J., Tal, E., Suppression of prolactin and thyrotropin secretion in the rat by antiserum to thyrotropin-releasing hormone. Endocrinology 100 (1977), 1476-1478.

40. Köbberling, J., Darragh, A., del Pozo, E., Chronic dopamine receptor stimulation using bromocriptine: Failure to modify thyroid function. Clinical Endocrinology 11 (1979), 367-370.

41. Kuku, S. F., Child, D. F., Nader, S., Fraser, T. R., Thyrotrophin and prolactin responsiveness to thyrotrophin releasing hormone in Cushing's disease. Clinical Endocrinology 4 (1975), 437-442.

42. Labrie, F., Drouin, J., Ferlang, L., Lagacé, L., Beaulieu, M., de Léan, A., Kelly, P. A., Caron, M. G., Raymoud, V., Mechanism of action of hypothalamic hormones in the anterior pituitary gland and specific modulation of their activity by sex steroids and thyroid hormones. In: Rec. Progr. Horm. Res. 34 (1978), $25-93$.

43. Jacobs, L. S., Snyder, P. J., Utiger, R. D., Daughaday, W. H., Prolactin response to thyrotropin-releasing hormone in normal subjects. J. Clin. Endocrinol. Metab. 36 (1973), 1069-1070.

44. Lechan, R. M., Jackson, I. M. D., Immunohistochemical localization of thyrotropin releasing hormone in the rat hypothalamus and pituitary. Endocrinology 11 (1982), 55- 65 .

45. L'Hermite, M., Vanhaelst, L., Copinschi, G., Leclercq, R., Goldstein, L., Bruno, O. D., Robyn, C., Prolactin release after injection of thyrotrophin releasing hormone in man. Lancet $I$ (1972), 763-764.

46. Mallik, T. K., Wilber, J. F., Pegues, J., Measurements of thyrotropin-releasing hormone like material in human peripheral blood by affinity chromatography and radioimmunoassay. J. Clin. Endocrinol. Metab. 54 (1982), 1194-1198.

47. Martin, J. B., Boshans, R., Reichlin, S., Feedback regulation of TSH-secretion in rats with hypothalamic lesions. Endocrinology 87 (1970), 1032-1040.

48. Massara, F., Camanni, F., Amoroso, A., Molinatti, G. M., Müller, E. E., Increased thyrotrophin and prolactin secretion induced by domperidone in hypothyroid subjects. Acta Endocrinol. (Kbh) 97 (1981) 48--53.

49. Maurer, R. A., Thyroid hormone specifically inhibits prolactin synthesis and decreases prolactin messenger ribonucleic acid levels in cultured pituitary cells. Endocrinology 110 (1982), $1507-1520$.

50. Mitsuma, T., Hirooka, Y., Nihei, N., Radioimmunoassay of thyrotrophin releasing hormone in human serum and its clinical application. Acta Endocrinol. (Kbh) 83 (1976), 225-235.

51. Mongioi, A., Aliffi, A., Vicari, E., Coniglione, F., Scapagnini, U., D'Agata, R., Down-regulation of prolactin secretion in men during continuous thyrotropin-releasing hormone infusion: Evidence of induction of pituitary desensitization by continuous TRH administration. J. Clin. Endocrinol. Metab. 56 (1983), 904-907.

52. Montoya, E., Seidel, M. J., Wilber, J. F., Thyrotropin-releasing hormone secretory physiology: Studies by radioimmunoassay and affinity chromatography. Endocrinology 96 (1975), 14131418 .

53. Nillson, K. O., Thorell, J. I., Hökfelt, D., The effect of thyrotrophin releasing hormone on the release of thyrotrophin and other pituitary hormones in man under basal conditions and following adrenergic blocking agents. Acta Endocrinol. (Kbh) 76 (1974), 24-34.

54. Otsuki, M., Dakoda, M., Baba, S., Influence of glucocorticoids on TRH-induced TSH-response in man. J. Clin. Endocrinol. Metab. 36 (1973), 95-102. 
55. Petersen, V. B., McGregor, A. M., Belchetz, P. E., Elkeles, R. S., Hall, R., The secretion of thyrotrophin with impaired biological activity in patients with hypothalamic-pituitary disease. Clinical Endocrinology 8 (1978), 397-402.

56. Pickardt, C. R., Geiger, W., Fahlbusch, R., Scriba, P. C., Stimulation der TSH-Sekretion durch TRF-Belastung bei hypothalamischen und hypophysären Krankheitsbildern. Klin. Wschr. 50 (1972), 42-52.

57. Pickardt, C. R., Erhardt, F., Fahlbusch, R., Scriba, P. C., Portal vessel occlusion: A cause for pituitary insufficiency in patients with pituitary tumors? Europ. J. Clin. Invest. 3 (1973), 262.

58. Pickardt, C. R., Erhardt, F., Fahlbusch, R., Grüner, J., Scriba, P. C., The diagnostic significance of the stimulation of TSH secretion by thyrotropin releasing hormone (TRH) administration in diseases of the hypothalamus and pituitary. Excerpta Med. (Amsterdam) ICS 306 (1973), 105-107.

59. Pickardt, C. R., Erhardt, F., Grüner, J., Heinze, H. G., Horn, K., Scriba, P. C., Stimulierbarkeit der TSH-Sekretion durch TRH bei autonomen Adenomen der Schilddrüse. Dtsch. med. Wschr. 98 (1973), 152-1.57.

60. Pickardt, C. R., Theisen, F., Witte, A., Leisner, B., Theisen, K., Jahrmärker, H., Effects of long-term treatment with amiodarone on thyroid function and thyroidal iodine concentration. In: New Aspects in the Medical Treatment of Tachyarrhythmias-Role of Amiodarone (Breithardt, G., Loogen, F, eds.), pp. 245-248. München-Wien-Baltimore: Urban \& Schwarzenberg. 1983.

61. Pieters, G. F. F., Smals, A. G. H., Goverde, H. J. M., Pesman, G. J., Meyer, E., Kloppenborg, P. W. C., Adrenocorticotropin and cortisol responsiveness to thyrotropin-releasing hormone and luteinizing hormone-releasing hormone discloses two subsets of patients with Cushings's disease. J. Clin. Endocrinol. Metab. 55 (1982), 1188-1197.

62. Rabello, M. M., Snyder, P. J., Utiger, R. D., Effects on the pituitary-thyroid axis and prolactin secretion of single and repetitive oral doses of thyrotropin-releasing hormone (TRH). J. Clin. Endocrinol. Metab. 39 (1974), 571-578.

63. Refetoff, S., Fang, V. S., Rapoport, B., Friesen, H. G., Interrelationships in the regulation of TSH and prolactin secretion in man: Effects of L-Dopa, TRH and thyroid hormone in various combinations. J. Clin. Endocrinol. Metab. 38 (1974), 450-457.

64. Roti, E., Gnudi, A., Robuschi, G., Emanuele, R., Benassi, L. J., Braverman, L. E., Response of growth hormone to thyrotropinreleasing hormone during fetal life. J. Clin. Endocrinol. Metab. 54 (1982), 1255-1257.

65. Sack, J., Fisher, D. A., Grajwer, L. A., Lam, R. W., Wang, C. C., The response of newborn sheep to TRH with and without somatostatin. Endocrinology 100 (1977), 1533-1538.

66. Scanlon, M. F., Weightman, D. R., Shale, D. J., More, B., Heath, M., Snow, M. H., Lewis, M., Hall, R., Dopamine is a physiological regulator of thyrotrophin (TSH) secretion in normal man. Clin. Endocrinol. 10 (1979), 7-15.

67. Scinlon, M. F., Wechman, A. D., Lewis, M., Pourmand, M., Rodriguez-Arnao, W. D., Weightman, D. R., Hall, R., Dopaminergic modulation of circadian thyrotrophin rhythms and thyroid hormone levels in euthyroid subjects. J. Clin. Endocrinol. Metab. 51 (1980), 1251-1256.

68. Scanlon, M. F., Rodriguez-Arnao, M. D., McGregor, A. M., Weightman, D., Lewis, M., Cook, D. B., Gomez-Pan, A., Hall, R., Altered dopaminergic regulation of thyrotrophin release in patients with prolactinomas: comparison with other tests of hypothalamic-pituitary function. Clinical Endocrinology 14 (1981), 133-143.

69. Scriba, P. C., Erhardt, F., Heinze, H. G., Horn, K., Marschner, I., Pickardt, C. R., Anterior pituitary and TSH. In: Regulation of
Thyroid Function (Klein, E., Reinwein, D., eds.), pp. 35-46. Stuttgart-New York: Schattauer. 1976.

70. Scriba, P. C., Bauer, M., Emmert, D., Fateh-Moghadam, A., Hofmann, G. G., Horn, K., Pickardt, C. R., Effects of obesity, total fasting and re-alimentation on L-thyroxine (T 4),3,5,3'-Ltriiodothyronine (T 3, 3, $3^{\prime}, 5^{\prime}$-L-triiodothyronine ( $\mathrm{rT} 3$ ), thyroxine binding globulin (TBG), cortisol, thyrotrophin, cortisol binding globulin (CBG), transferrin, a 2-haptoglobin and complement C'3 in serum. Acta Endocrinol. (Kbh) 91 (1979), $629-643$.

71. Shambaugh III G. E., Wilber, J. F., Montoya, E., Ruder, H., Blonsky, E. R., Thyrotropin-releasing hormone (TRH): Measurements in human spinal fluid. J. Clin. Endocrinol. Metab. 41 (1975), 131-134.

72. Snyder, P. J., Jacobs, L. S., Utiger, R. D., Daughaday, W. H., Thyroid hormone inhibition of the prolactin response to thyrotropin-releasing hormone. J. Clin. Invest. 52 (1973), 2324 2329.

73. Sowers, J. R., Carlson, H. E., Brautbar, N., Hershman, J. M., Effect of dexamethasone on prolactin and TSH responses to TRH and metoclopramide in man. J. Clin. Endocrinol. Metab. 44 (1977), 237-241.

74. Sowers, J. R., Catania, R. A., Hershman, J. M., Evidence for dopaminergic control of circadian variations in thyrotropin secretion. J. Clin. Endocrinol. Metab. 54 (1982), 673- 675.

75. Staub, J. J., Girard, J., Mueller-Brand, J., Noelpp, B., WernerZodrow, I., Baur, U., Heitz, Ph., Gemsenjaeger, E., Blunting of TSH response after repeated oral administration of TRH in normal and hypothyroid subjects. J. Clin. Endocrinol. Metab. 46 (1978), 260-266.

76. Szabo, M., Kovathana, N., Gordon, K., Frohman, L. A., Effect of passive immunization with an antiserum to thyrotropin (TSH)-releasing hormone on plasma TSH levels in thyroidectomized rats. Endocrinology 102 (1978), 799- 805.

77. Tashjian, A. H., Barowksy, N. J., Jensen, D. K., Thyrotropin releasing hormone: Direct evidence for stimulation of prolactin production by pituitary cells in culture. Biochem. Biophys. Res. Comm. 43 (1971), 516.

78. Urman, S., Critchlow, V., Long term elevations in plasma thyrotropin but not growth hormone, concentrations associated with lesion-induced depletion of median eminence somatostatin. Endocrinology 112 (1983), 659-644.

79. Vale, W., Rivier, C., Brazeau, P., Guillemin, R., Effects of somatostatin on the secretion of thyrotropin and prolactin. Endocrinology 95 (1974), 968-983.

80. Wartofsky, L., Burman, K. D., Alterations in thyroid function in patients with systemic illness: The "euthyroid sick syndrome". Endocrine Reviews 3 (1982), 164-217.

81. Wenzel, K. W., Döring, J., Lack of influence of the antidopaminergic drug domperidone on basal and TRH-stimulated TSHserum levels after oral administration. Acta Endocrinol. (Kbh) $101(1982), 550-554$.

82. von Werder, K., Wachstumshormone und Prolaktin. Urban \& Schwarzenberg. 1975.

83. von Werder, K., Fahlbusch, R., Gay, R., Pickardt, C. R., Schultz, B., Stimulation der Wachstumshormon- und ProlaktinSekretion durch TRH bei Akromegalie. Klin. Wschr. 54 (1976), 335.

84. Wilber, J. F., Utiger, R. D., The effect of glucocorticoids on thyrotropin secretion. J. Clin. Invest. 48 (1969), 2096-2103.

Author's address: Dr. C. R. Pickardt, Medizinische Klinik Innenstadt der Universität München, Ziemssenstrasse 1, D-8000 München, Federal Republic of Germany. 